\title{
Iron oxides dynamics in a subtropical Brazilian Paleudult under long-term no-tillage management
}

\author{
Alberto Vasconcellos Inda ${ }^{1}$, José Torrent ${ }^{2}$, Vidal Barrón ${ }^{2}$, Cimélio Bayer ${ }^{1}$, Jessé Rodrigo Fink ${ }^{1}$
}

IUFRGS/FA - Depto. de Solos, Av. Bento Gonçalves, 7712, C.P. 15100 - 97105-400 - Porto Alegre, RS - Brasil.

2Universidad de Córdoba - Depto. de Agronomía, Campus de Rabanales, Edificio C4 - 14071 - Córdoba - Spain.

*Corresponding author <alberto.inda@ufrgs.br>

Edited by: José Miguel Reichert

Received December 15, 2011

Accepted May 01, 2012
ABSTRACT: Replacing conventional tillage (CT) with no-tillage (NT) management alters the pedoenvironment and the rate of topsoil processes, with possible effects on dissolution processes associated with iron oxides and therefore soil mineralogy. This study aimed to determine the effect of NT on the content and distribution of types of iron oxides in a Rhodic Paleudult in southern Brazil. Soil samples were collected at eight depths within the 0.00-0.80 m layer under CT and NT in a long-term experiment (21 years). Mineralogical identification was conducted by X-ray diffraction (XRD), and the Fe content related to specific types of iron oxides determined by selective dissolution and diffuse-reflectance spectroscopy. Kaolinite, quartz, goethite, hematite, and maghemite were identified in the clay fraction. In the NT-managed soil, there was a decrease in the content of crystalline iron oxides and an increase in the content of poorly crystalline iron oxides with increasing proximity to the soil surface. These results suggest that iron oxides are rearranged in this soil by reductive dissolution of the crystalline types and neoformation of metastable ferrihydrite in topsoil layers, which should be assessed further in laboratory studies. Keywords: dissolution, ferrihydrite, hematite, maghemite, soil management

\section{Introduction}

Iron $(\mathrm{Fe})$ oxides (here including oxides, hydroxides and oxyhydroxides) influence the physical and chemical behavior of tropical and subtropical soils (Bigham et al., 2002; Cornell and Schwertmann, 2003). Because the formation and stability of several minerals in this group are determined by specific conditions, Fe oxides are also indicators of the pedoenvironment (current and past) and pedogenetic processes (Schwertmann and Taylor, 1989; Bigham et al., 2002).

Although models for the formation of Fe oxides in aerobic soils indicate that these minerals exhibit high thermodynamic stability and low solubility, and remain in the soil for long periods of time (Bigham et al., 2002), several authors have found mineralogical alterations indicative of environmental changes during pedogenesis (Fitzpatrick and Schwertmann, 1982; Muggler et al., 2001). Thus, considering recent changes in the soil environment, Silva Neto et al. (2008) proposed to investigate the effect of notillage $(\mathrm{NT})$ on the dynamics of Fe oxides in soils previously under conventional tillage (CT) management. This new condition, characterized by an increased organic matter content and lability, moisture content, and microbial activity, favors reduction and complexation, which are the main dissolution reactions for iron oxides in pedogenic environments (Schwertmann, 1991). This hypothesis was tested by Silva Neto et al. (2008) in an Oxisol cultivated for 18 years under NT management, and the authors observed alterations in distribution of the total content of pedogenic Fe oxides and the mineral forms with low crystallinity. Although the Fe levels of types of Fe oxides were not discriminated, the authors suggested that the new conditions in the NT-managed topsoil layer promoted reductive dissolution of some crystalline types (hematite and maghemite) and neoformation of metastable types of low crystallinity (ferrihydrite).

A study conducted on the Switzerland-Italy border revealed that recent changes $(20-50$ years $)$ in forest vegetation affected the total content of pedogenic Fe oxides [as measured by the dithionite-extratable $\left.\mathrm{Fe}\left(\mathrm{Fe}_{\mathrm{d}}\right)\right]$, the content of $\mathrm{Fe}$ oxides of low crystallinity [as measured by the oxalate-extractable $\left.\mathrm{Fe}\left(\mathrm{Fe}_{\text {ox }}\right)\right]$ and the $\mathrm{Fe}_{\text {ox }} / \mathrm{Fe}_{\mathrm{d}}$ ratio, which were related to alterations of the soil organic matter content and quality (Zanelli et al., 2007). Under laboratory conditions, Liptzin and Silver (2009) observed dissolution of $\mathrm{Fe}$ oxides after incubating soil with a mixture of organic compounds extracted from leaf litter. The authors suggested that the mobilization of Fe oxides is due to altered reducing conditions in micro sites of soil saturated with water during and after rainfall events, when microbial reduction of $\mathrm{Fe}^{3+}$ to soluble $\mathrm{Fe}^{2+}$ occurs. This is followed by oxidizing conditions, under which new iron oxide types are formed.

Despite the limited literature on the subject, there is evidence that recent use and management of soils may change Fe oxide mineralogy. Assessing these alterations will contribute to increase the knowledge of the physical and chemical behavior of tropical and subtropical NT-managed soils. Considering that different types of pedogenic iron oxides have distinct dissolution stabilities (Torrent et al., 1987; Bryant and Macedo, 1990; Jeanroy et al., 1991), this study aimed to determine the effect of long-term NT management on content and distribution of Fe relative to the types of iron oxides (goethite, hematite, maghemite, and ferrihydrite) in a subtropical Rhodic Paleudult compared to its CT-managed counterpart. In addition, it aimed to assess the effect of mineralogical alterations on the specific surface area of the soil clay fraction. 


\section{Materials and Methods}

\section{Setting and experimental site}

A long-term (21-year) experiment was conducted in a Rhodic Paleudult (Argissolo Vermelho Distrófico by the Brazilian Soil Classification System - Embrapa, 2006) located in Eldorado do Sul, Rio Grande do Sul state, Brazil $\left(30^{\circ} 06^{\prime} \mathrm{S} ; 51^{\circ} 40^{\prime} \mathrm{W}\right)$. The area has a subtropical humid Cfa-type climate according to the Köppen classification, with an average annual temperature of $19.2^{\circ} \mathrm{C}$ and rainfall of 1,440 mm per year (Bergamaschi et al., 2003). The soil in the study area originated from alteration of granitic rocks formed during the Precambrian period, and the original vegetation type of the region is native grassland.

The soil has an increment in clay content from the top layer $\left(228 \mathrm{~g} \mathrm{~kg}^{-1}\right)$ to the deepest layer $\left(418 \mathrm{~g} \mathrm{~kg}^{-1}\right)$, due to the presence of the argillic horizon. The soil properties under native grassland $(0.00-0.30 \mathrm{~m})$ were the following: $228 \mathrm{~g} \mathrm{~kg}^{-1}$ clay, $240 \mathrm{~g} \mathrm{~kg}^{-1}$ silt, $532 \mathrm{~g} \mathrm{~kg}^{-1}$ sand, $12 \mathrm{~g} \mathrm{~kg}^{-1}$ organic matter, $\mathrm{pH} \mathrm{H}_{2} \mathrm{O}=4.7$, $\mathrm{P}=5 \mathrm{mg} \mathrm{dm}^{-3}, \mathrm{~K}=4.1 \mathrm{mmol}_{\mathrm{c}} \mathrm{dm}^{-3}, \mathrm{Al}^{3+}=9.5 \mathrm{mmol}_{\mathrm{c}} \mathrm{dm}^{-3}$, $\mathrm{Ca}^{2+}+\mathrm{Mg}^{2+}=29.0 \mathrm{mmol}_{\mathrm{c}} \mathrm{dm}^{-3}$, and CEC $=85 \mathrm{mmol}_{\mathrm{c}} \mathrm{dm}^{-3}$.

The experiment was conducted at a site previously cultivated under CT management for 16 years (1969-1984). It was set in a randomized block design with split-plots and three replicates. The main plots $(15 \times 20 \mathrm{~m})$ were managed with three soil tillage systems (NT, CT, and MT-minimum tillage), and sub-plots $(5 \times 20 \mathrm{~m})$ included three cropping systems (oats/corn, vetch/corn, and oats + vetch/corn + cowpea).

For soil sampling, NT and CT treatments were evaluated under the following cropping systems: oats (Avena strigosa Schreb) + vetch (Vicia sativa L.)/corn (Zea mays L.) + cowpea (Vigna unguiculata (L.) Walp.). Every year, winter cover-crops were row-sown in Apr. or May (Aut.) under NT system in both treatments. Tillage systems were applied once a year in spring before corn sowing. The CT plots were ploughed to a furrow-depth of $17 \mathrm{~cm}$ and harrowed twice to a depth of $10 \mathrm{~cm}$ using a disk harrow mixing the winter crops residues in this layer. In NT system, winter cover crops were killed using a glyphosate-based herbicide and crops residues maintained on soil surface. Corn was sown in Sep. or Oct. using a three-line seeding seed drill. Cowpea was manually sown between corn lines about 15-20 days after corn sowing.

\section{Soil sampling and preparation}

Soil was sampled at depths of $0.00-0.025,0.025$ $0.05,0.05-0.10,0.10-0.15,0.15-0.20$, and $0.20-0.30 \mathrm{~m}$ in the three experimental site replicates for each soil management system (CT and NT). To observe the behavior of iron oxides at greater depths, a composite soil sample was prepared from material taken at depths of 0.40-0.60 and $0.60-0.80 \mathrm{~m}$ in each treatment. At a site adjacent to the experiment, a composite sample was also obtained from material collected at a depth of $0.00-0.30 \mathrm{~m}$ (A horizon) of soil under native grassland, as a reference to identify the soil mineralogical composition.
The samples were air-dried, loosened, and passed through a sieve to obtain the air-dried fine soil (ADFS) fraction $(\varnothing<2 \mathrm{~mm})$. The total clay fraction $(\varnothing<0.002 \mathrm{~mm})$ was obtained by sedimentation according to Stokes's Law after dispersing the soil using ultrasound without adding a chemical dispersant, and sieving the sand fraction (2 $\mathrm{mm}>\varnothing>0.053 \mathrm{~mm}$ ). Then, 20-g ADFS was suspended in $80 \mathrm{~mL}$ of distilled water into $100-\mathrm{mL}$ centrifuge tubes, and subjected to $240 \mathrm{~J} \mathrm{~mL}^{-1}$ of energy in a Vibracel ultrasound machine (SONICS \& MATERIALS, model VC750) equipped with a $136 \mathrm{~mm}$ long $\times 13 \mathrm{~mm}$ diameter probe. The energy required for the complete dispersion of soil primary particles was estimated from a previously determined calibration curve (North, 1976).

The suspended clay fraction was flocculated using a $0.1 \mathrm{~mol} \mathrm{~L}^{-1} \mathrm{HCl}$ solution, washed with ethanol/ water (1:1), and dried in an oven at $60{ }^{\circ} \mathrm{C}$. Iron oxides were concentrated by treating the total clay fraction with a heated solution of $5 \mathrm{~mol} \mathrm{~L}^{-1} \mathrm{NaOH}$ (Kämpf and Schwertmann, 1982).

\section{Total organic carbon}

Total organic carbon (TOC) levels in the ADFS fraction were determined by dry combustion in a SHIMADZU VCSH carbon analyzer. The organic C relative to the low molecular weight organic compounds was extracted with $0.1 \mathrm{~mol} \mathrm{~L}^{-1} \mathrm{HCl} / 1 \mathrm{~g}$ soil in $20 \mathrm{~mL}$ $\mathrm{HCl}$ ), after $2 \mathrm{~h}$ of horizontal shaking, and determined by spectrophotometry (Silva Neto et al., 2008).

\section{X-ray diffraction}

The mineralogical composition of the total clay fraction at a depth of 0.00-0.30 $\mathrm{m}$ was determined by X-ray diffraction (XRD) (Siemens D5000 diffractometer with $\mathrm{CoK} \alpha$ radiation and a Fe filter at a voltage of $40 \mathrm{kV}$ and a current of $25 \mathrm{~mA}$ ). Analyses were conducted on nonoriented slides for the total clay fraction (range $4-60^{\circ} 2 \theta$ ) and the iron oxide concentrate fraction (range $20-60^{\circ} 2 \theta$ ). The minerals were identified based on the diffraction constant data provided by Brown and Brindley (1980).

\section{Diffuse reflectance spectroscopy}

The hematite/(hematite + goethite) iron oxide ratio $(\mathrm{Hm} / \mathrm{Hm}+\mathrm{Gt})$ was estimated by diffuse reflectance spectroscopy (Torrent and Barrón, 1993; Torrent and Barrón, 2008) in finely ground total clay samples from depths of $0.00-0.025$, $0.05-0.10$, and $0.20-0.30 \mathrm{~m}$ under both soil management systems (CT and NT). The spectra were recorded at $0.5-\mathrm{nm}$ intervals within the $380-900 \mathrm{~nm}$ wavelength range in a CARY 1E UV-Visible spectrophotometer equipped with an integrating sphere $73 \mathrm{~mm}$ in diameter. $\mathrm{BaSO}_{4}$ was used as the white standard $($ reflectance $=100 \%)$; the reflectance minimum $(0 \%)$ was obtained by placing a black stripe at the entrance of the light beam.

The reflectance (R) spectra were transformed into the Kubelka-Munk (remission) function spectra and then into the respective second derivative spectra (Torrent and Barrón, 2008). The relative intensities of the bands between 
$\pm 410-445 \mathrm{~nm}\left(\mathrm{I}_{\mathrm{G}}\right)$ and between $\pm 530-580 \mathrm{~nm}\left(\mathrm{I}_{\mathrm{Hm}}\right)$ were measured and the $\mathrm{I}_{\mathrm{Hm}} /\left(\mathrm{I}_{\mathrm{Hm}}+\mathrm{I}_{\mathrm{Gt}}\right)$ ratio was use to estimate the iron oxide ratio $(\mathrm{Hm} / \mathrm{Hm}+\mathrm{Gt})$ according to Torrent and Barron (2008). Maghemite contributes to the 410 - $445 \mathrm{~nm}$ band of goethite; however because the contents of maghemite were substantially lower than those of hematite plus goethite (Figure 5) and maghemite has less reflectivity than goethite, we neglected the influence of the maghemite in the $\mathrm{Hm} /(\mathrm{Hm}+\mathrm{Gt})$ ratio.

\section{Fe content}

The Fe forms contents were extracted in the total clay fraction. The $\mathrm{Fe}$ in pedogenic iron oxides $\left(\mathrm{Fe}_{\mathrm{d}}\right)$ was extracted with dithionite-citrate-bicarbonate at $80{ }^{\circ} \mathrm{C}$ (Mehra and Jackson, 1960). The Fe in Fe oxides of low crystallinity (basically ferrihydrite, $\mathrm{Fe}_{\mathrm{Fh}}$ ) was extracted using $0.2 \mathrm{~mol} \mathrm{~L}^{-1}$ ammonium oxalate at $\mathrm{pH} 3$ in darkness (Schwertmann, 1964).

The $\mathrm{Fe}$ in maghemite $\left(\mathrm{Fe}_{\mathrm{Mh}}\right)$ was calculated using the formula $\mathrm{Fe}_{\mathrm{Mh}}=\mathrm{FeH}_{2} \mathrm{SO}_{4}-\mathrm{Fe}_{\mathrm{Fh}^{\prime}}$ in which $\mathrm{FeH}_{2} \mathrm{SO}_{4}$ is the $\mathrm{Fe}$ extracted by $1.8 \mathrm{~mol} \mathrm{~L}^{-1} \mathrm{H}_{2} \mathrm{SO}_{4}$ at $80^{\circ} \mathrm{C}$ for $45 \mathrm{~min}$ (Schwertmann and Fechter, 1984, modified). This selective dissolution method can result in overestimation of the maghemite content because significant amounts of other $\mathrm{Fe}$ oxides can be dissolved. In fact, if a value of $600 \times 10^{-6} \mathrm{~m}^{3} \mathrm{~kg}^{-1}$ is taken as the magnetic susceptibility of maghemite, the value of about $1.8 \times 10^{-6} \mathrm{~m}^{3} \mathrm{~kg}^{-1}$ observed for the studied soils corresponds to a maghemite content of about $3 \mathrm{~g} \mathrm{~kg}^{-1}$ soil (i.e. a value substantially lower than the 1 shown in Figure 5). In any case, the maghemite contents estimated by the two methods are highly correlated (results not shown). After this time (45 min), the mass-specific magnetic susceptibility $(\chi)$ at a low frequency $\left(465 \mathrm{~Hz}, \chi_{\mathrm{ff}}\right)$ reached a value close to zero (Figure 1), indicating the total dissolution of maghemite in the investigated soil. Magnetic susceptibility analysis was conducted in a Bartington MS2B susceptibility meter. The Fe in the form of hematite $(\mathrm{Hm})$ and goethite $(\mathrm{Gt})$ was calculated using the formula $\mathrm{Fe}_{\mathrm{Hm}+\mathrm{Gt}}=\left[\mathrm{Fe}_{\mathrm{d}}-\left(\mathrm{Fe}_{\mathrm{Fh}}+\mathrm{Fe}_{\mathrm{Mh}}\right)\right]$. The Fe levels solubilized by different extractants were determined by atomic absorption spectroscopy (AAS).

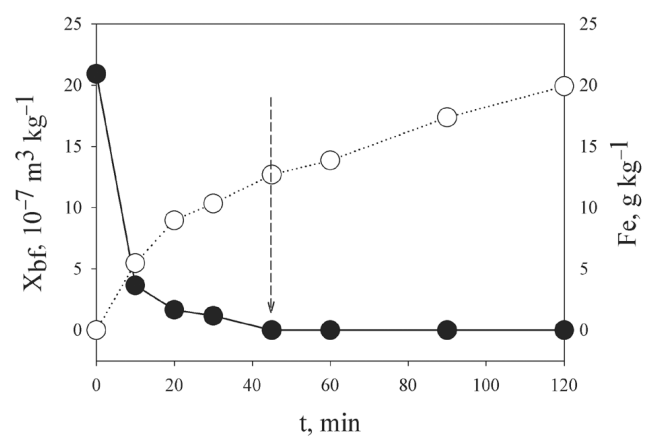

Figure 1 - Magnetic susceptibility at low frequency $\left(\chi_{\mathrm{ff}}\right)(\bullet)$ and the dissolved Fe content in $1.8 \mathrm{~mol} \mathrm{~L}^{-1} \mathrm{H}_{2} \mathrm{SO}_{4}(\mathrm{O})$ at the time of extraction from the $0.00-0.30 \mathrm{~m}$ layer in the total clay fraction of the investigated Rhodic Paleudult. The dashed arrow indicates the extraction time after that the magnetic susceptibility is zero.

\section{Specific surface area}

The specific surface area (SSA) of the total clay fraction was determined using the water adsorption method at $20 \%$ relative humidity (Quirk, 1955) and by the BET method using $\mathrm{N}_{2}$ gas as an adsorbent in a Micromeritics ASAP 2010 apparatus.

\section{Data analysis}

The data on the average Fe levels and specific surface area in the $0.00-0.30 \mathrm{~m}$ layer under different soil management systems were subjected to analysis of variance, and differences between averages were evaluated by Tukey's test $(p<0.05)$. The behavior of the Fe content associated with different iron oxide types and the specific surface area within the 0.00-0.30 m layer were evaluated based on a set of linear regressions, while the significance of the correlation coefficients was evaluated to identify the main soil variables that control the magnitude of the specific surface area of soil under different management systems.

\section{Results and Discussion}

Replacing CT with NT management resulted in a more pronounced accumulation of soil organic $\mathrm{C}$ at depths of 0.00-0.025 and 0.025-0.05 $\mathrm{m}$ (Figure 2). The 0.00-0.05 m layer in the NT-managed soil exhibited a $65 \%$ higher average organic $\mathrm{C}$ content compared to the CT-managed soil (24.6 and $14.9 \mathrm{~g} \mathrm{~kg}^{-1}$, respectively). This increased organic C content in the topsoil layers of the NT-managed soil has been widely reported in the literature (Dieckow et al., 2009; Santos et al., 2011) because of the less oxidative environment and the above ground biomass addition on the surface layers of the NT-managed soil (Bayer et al., 2006). These are also factors that contribute to an increased $\mathrm{C}$ content relative to the low molecular weight organic compounds $\left(\mathrm{C}_{\mathrm{HCl}}\right)$, which was nearly twice that of the CT-managed soil (Figure 2, in detail). Such results support the assumption of a new condition in the soil en-

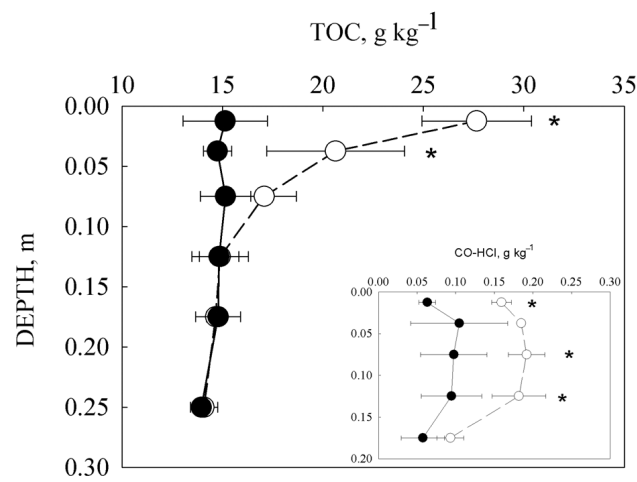

Figure 2 - Total organic carbon (TOC) and low molecular weight organic carbon compound $\left(\mathrm{C}_{\mathrm{HCl}}\right)$ levels in the ADFS fraction within the topsoil layer of a Rhodic Paleudult under conventional tillage $(\bullet)$ and no-tillage $(O)$ soil management. Horizontal bars indicate the standard deviation. *indicates that the averages for the two management systems differ (Tukey's test, $p<0.05$ ). 
vironment given the recent change in the management of tillage system.

The X-ray diffraction patterns in samples $(0.00-0.30 \mathrm{~m}$ layer) from native grassland area revealed the predominance of kaolinite $(0.72 \mathrm{~nm})$ and quartz $(0.33 \mathrm{~nm})$ in the total clay fraction as well as low levels of mica (1.02 $\mathrm{nm})$ and 2:1 minerals $(1.42 \mathrm{~nm})$ (Figure 3A). Although the dissolution of kaolinite was incomplete in the iron oxide concentration treatment, the XRD of this fraction allowed the identification of the goethite, hematite, and maghemite (Figure 3B). Estimates of the $\mathrm{Hm} /(\mathrm{Hm}+\mathrm{Gt})$ ratio obtained by diffuse reflectance (between 0.31 and 0.33 ) indicated that goethite predominates over hematite, that ratio remaining practically constant within the topsoil layer under the two management systems (Table 1).

Considering that the experimental area experienced almost two decades of soil cultivation based in

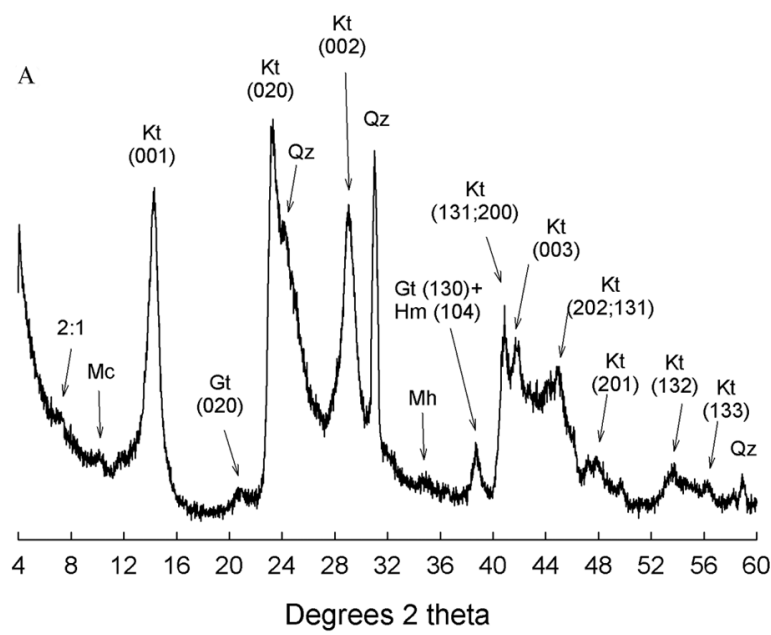

B

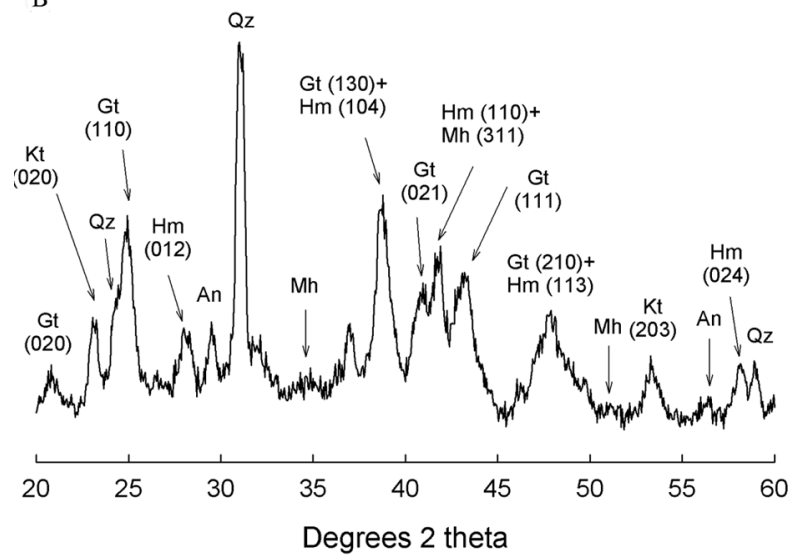

Figure 3 - X-ray diffractograms of the total clay fractions $(A)$ and iron oxide concentrates (B) from the 0.00-0.30 m layer of the investigated Rhodic Paleudult under native grassland. Kt - kaolinite, $\mathrm{Qz}$ - quartz, Mc - mica, $\mathrm{Mh}$ - maghemite, $\mathrm{Hm}$ - hematite, Gt - goethite, An - anatase. conventional tillage practices, soil under native vegetation should not be considered a suitable reference. Thus, NT effect on soil iron oxides was analyzed in comparison to the conventionally-tilled soil, which soil shown the same initial condition of no-tilled soil. As for the Fe forms in the 0.00-0.30 m layer, the NT management did not alter the contents in pedogenic Fe oxides $\left(\mathrm{Fe}_{\mathrm{d}}\right), \mathrm{Fe}$ oxides of low crystallinity $\left(\mathrm{Fe}_{\mathrm{Fh}}\right)$, maghemite $\left(\mathrm{Fe}_{\mathrm{Mh}}\right)$, or hematite and goethite $\left(\mathrm{Fe}_{\mathrm{Hm}+\mathrm{Gt}}\right)$ (Table 2). However, using NT management for 21 years resulted in a distinct behavior of the Fe levels in this layer compared to CT (Figures 4 and 5), similar to that observed by Silva Neto et al. (2008). In the CT-managed soil, the $\mathrm{Fe}_{\mathrm{d}}$ and $\mathrm{Fe}_{\mathrm{Fh}}$ levels exhibited a negative relationship with depth, so they increased by $7 \%\left(2.9 \mathrm{~g} \mathrm{~kg}^{-1}\right)$ and $68 \%\left(2.6 \mathrm{~g} \mathrm{~kg}^{-1}\right)$, respectively, from the 0.20-0.30 m layer to the 0.00-0.025 m layer. However, this trend was not observed for the 0.00-0.15 m layer, possibly due to the homogenization caused by the intense tillage performed each year under CT management.

In the NT-managed soil, the trend of $\mathrm{Fe}_{d}$ with depth was the opposite of that observed in the CT-managed soil, i.e., there was a decrease of $20 \%\left(8.2 \mathrm{~g} \mathrm{~kg}^{-1}\right)$ with increasing proximity to the soil surface (Figure 4). This decrease of $\mathrm{Fe}_{\mathrm{d}}$ towards the uppermost soil layers in the NT-managed soil was not due to Fe oxides with low crystallinity $\left(\mathrm{Fe}_{\mathrm{Fh}}\right)$, the content of which was similar to that of the CT-managed soil, as it was clearly increase in the topsoil (Figure 4).

Table 1 - Amplitude of the absorption bands and the hematite/ (hematite+goethite) relationship obtained by diffuse reflectance spectrophotometry in total clay fraction samples.

\begin{tabular}{|c|c|c|c|}
\hline \multirow{2}{*}{$\begin{array}{l}\text { Layer, } \\
\mathrm{m}\end{array}$} & \multicolumn{2}{|c|}{ Amplitude } & \multirow{2}{*}{$\mathrm{Hm} /(\mathrm{Hm}+\mathrm{Gt})$} \\
\hline & Gt $410-445 \mathrm{~nm}$ & $\mathrm{Hm} 530-580 \mathrm{~nm}$ & \\
\hline \multicolumn{4}{|c|}{$-\times 10^{-3}$} \\
\hline \multicolumn{4}{|c|}{ СT } \\
\hline $0.00-0.025$ & 3.786 & 1.701 & 0.31 \\
\hline $0.05-0.10$ & 3.630 & 1.819 & 0.33 \\
\hline $0.20-0.30$ & 4.585 & 2.237 & 0.33 \\
\hline \multicolumn{4}{|c|}{ NT } \\
\hline $0.00-0.025$ & 3.686 & 1.717 & 0.32 \\
\hline $0.05-0.10$ & 3.055 & 1.447 & 0.32 \\
\hline $0.20-0.30$ & 4.057 & 1.865 & 0.31 \\
\hline
\end{tabular}

Gt- goethite, Hm- hematite, CT- conventional tillage, NT- no-tillage.

Table 2 - Average Fe content and specific surface area (SSA) of the total clay fraction in the $0.00-0.30$ m layer of a Rhodic Paleudult under conventional tillage (CT) and no-tillage (NT) management.

\begin{tabular}{|c|c|c|c|c|c|c|}
\hline $\begin{array}{l}\text { Management } \\
\text { system }\end{array}$ & $\mathrm{Fe}_{\mathrm{d}}$ & $\mathrm{Fe}_{\mathrm{Fh}}$ & $\mathrm{Fe}_{\mathrm{Mh}}$ & $\mathrm{Fe}_{\mathrm{Hm}+\mathrm{Gt}}$ & SSA- $\mathrm{H}_{2} \mathrm{O}$ & SSA-N ${ }_{2}$ \\
\hline & & $-g$ & & & $-m^{2}$ & $\mathrm{~g}^{-1}-$ \\
\hline CT & $43.8^{\text {ns }}$ & $5.0^{\text {ns }}$ & $10.7^{\mathrm{ns}}$ & $28.1^{\text {ns }}$ & $68.3^{\text {ns }}$ & $60.7^{\text {ns }}$ \\
\hline NT & 45.1 & 4.6 & 10.6 & 29.9 & 68.0 & 60.4 \\
\hline
\end{tabular}


The altered distribution of $\mathrm{Fe}_{d}$ levels in the NTmanaged soil was probably associated with the mobilization (dissolution/neoformation) and reordering of iron oxide types with higher crystallinity (goethite, hematite, and maghemite) (Figure 5). Although goethite and hematite differ in their stability towards reductive dissolution (Torrent et al., 1987; Bryant and Macedo, 1990; Jeanroy et al., 1991), the estimated $\mathrm{Hm} /(\mathrm{Hm}+\mathrm{Gt})$ relationship within the topsoil layer did not indicate changes in the relative proportion of these oxides (Table 1), allowing combined interpretation of the $\mathrm{Fe}$ in the form of $\mathrm{Hm}$ and $\mathrm{Gt}\left(\mathrm{Fe}_{\mathrm{Hm}+\mathrm{Gt}}\right)$.

In the CT-managed soil, the $\mathrm{Fe}_{\mathrm{Hm}+\mathrm{Gt}}$ levels showed a negative relationship with depth in the $0.00-0.30 \mathrm{~m}$ layer, with a slightly pronounced $(8 \%)$ range of variation being observed between the upper and lower layers, while the $\mathrm{Fe}_{\mathrm{Mh}}$ levels did not show a relationship with soil depth (Figure 5). In the NT-managed soil, the levels of $\mathrm{Fe}_{\mathrm{Hm}+\mathrm{Gt}}$ and $\mathrm{Fe}_{\mathrm{Mh}}$ exhibited positive relationships with depth, showing decreases of $32 \%\left(8.2 \mathrm{~g} \mathrm{~kg}^{-1}\right)$ and $27 \%\left(2.5 \mathrm{~g} \mathrm{~kg}^{-1}\right)$, respectively, with increasing proximity to the soil surface (Figure 5). In the NT-managed soil, the mobilization of maghemite, the main pedogenic ferrimagnetic mineral in the clay fraction (Fontes et al., 2000; Silva et al., 2010; Souza Junior et al., 2010), was confirmed by the magnetic susceptibility $\left(\chi_{\mathrm{lf}}\right)$ values, which presented a positive relationship with depth in the topsoil layer (Figure 5, in detail), and with the $\mathrm{Fe}_{\mathrm{Mh}}$ content $(r=0.658 ; p=0.003 ; n=18)$.

For the total clay fraction in the $0.00-0.30 \mathrm{~m}$ layer, as measured by water $\left(\mathrm{SSA}-\mathrm{H}_{2} \mathrm{O}\right)$ and nitrogen adsorption $\left(\mathrm{SSA}-\mathrm{N}_{2}\right)$, the average SSA values were not affected by the soil management system (Table 2). However, SSA de-

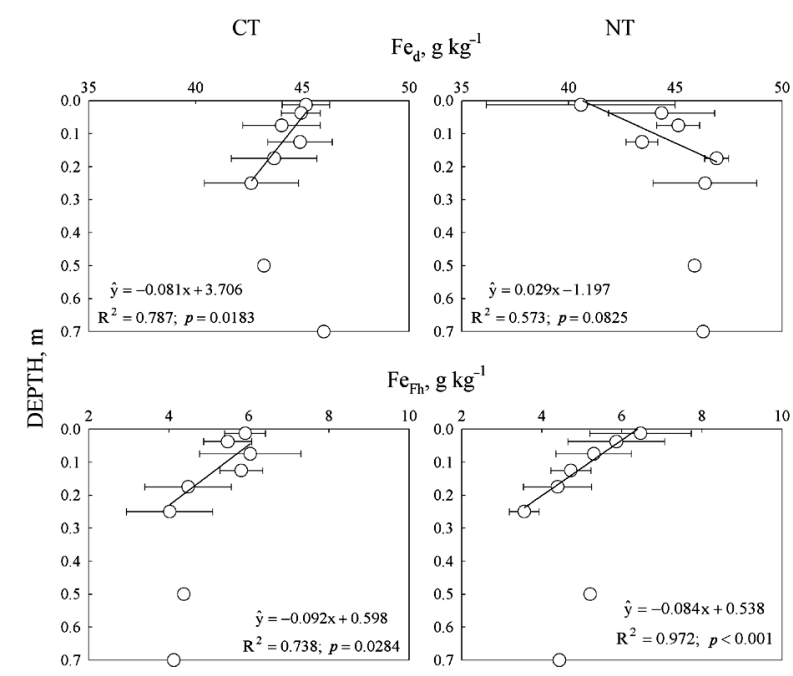

Figure 4 - Fe content of pedogenic iron oxides $\left(\mathrm{Fe}_{\mathrm{d}}\right)$ and iron oxides with low crystallinity $\left(\mathrm{Fe}_{\mathrm{Fh}}\right)$ from the total clay fraction within the topsoil layer of a Rhodic Paleudult under conventional tillage (CT) and no-tillage (NT) soil management. Horizontal bars indicate the standard deviation. creased with increasing proximity to the soil surface in the NT-managed soil (14 \% or $9.2 \mathrm{~m}^{2} \mathrm{~g}^{-1}$ for SSA-H $\mathrm{O}_{2} ; 41 \%$ or $21.5 \mathrm{~m}^{2} \mathrm{~g}^{-1}$ for SSA-N ${ }_{2}$ ) (Figure 6). No straightforward explanation can be offered for the lower SSA-N $\mathrm{N}_{2}$ compared to the SSA- $\mathrm{H}_{2} \mathrm{O}$ values. It can be hypothesized this is due to the higher affinity of the polar water molecule for hydroxilated mineral surfaces or effective blocking of the nonpolar nitrogen molecule by organic matter. However, no systematic differences are usually observed between the two surfaces in the case of pure Fe oxides (Colombo et al., 1994).

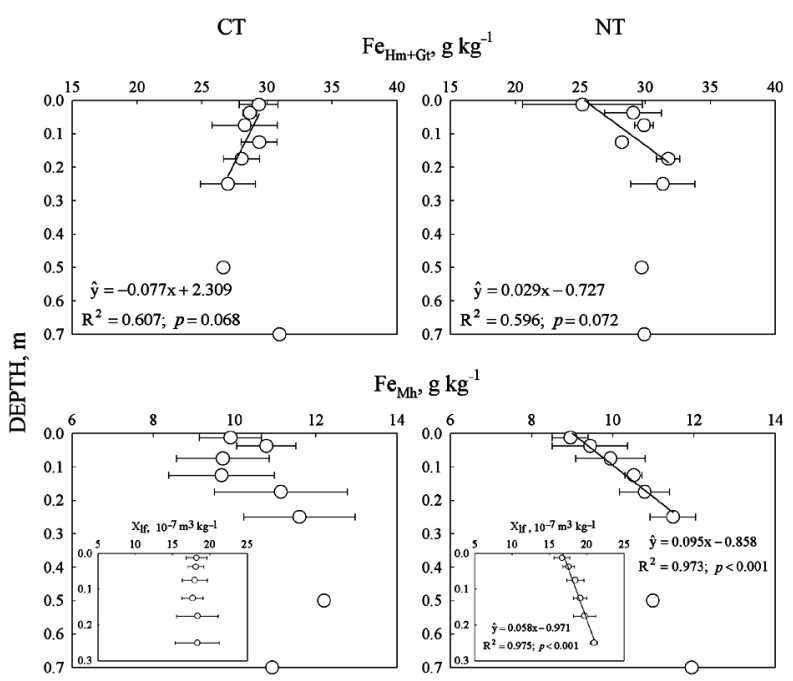

Figure 5 - Fe content of goethite and hematite iron oxides $\left(\mathrm{Fe}_{\mathrm{Hm}+\mathrm{Gi}}\right)$ and maghemite iron oxides $\left(\mathrm{Fe}_{\mathrm{Mh}}\right)$ and the magnetic susceptibility at low frequency $\left(\chi_{\mathrm{ff}}\right)$ (details) of the total clay fraction within the topsoil layer of a Rhodic Paleudult under conventional tillage (CT) and no-tillage (NT) soil management. Horizontal bars indicate the standard deviation.

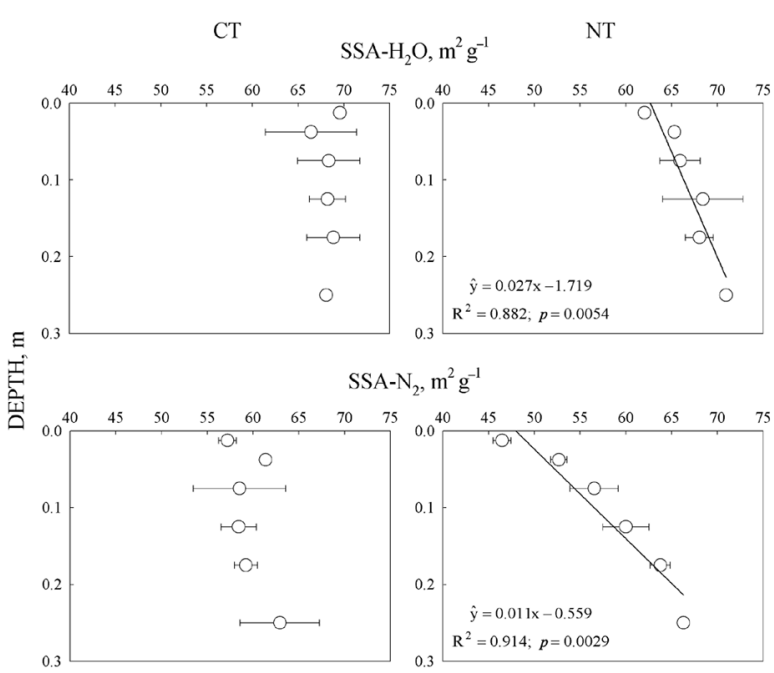

Figure 6 - Specific surface area (SSA) of the total clay fraction within the topsoil layer of a Rhodic Paleudult under conventional tillage (CT) and no-tillage (NT) soil management. Horizontal bars indicate the standard deviation. 
The levels of $\mathrm{Fe}_{\mathrm{d}^{\prime}} \mathrm{Fe}_{\mathrm{Mh}}$, and $\mathrm{Fe}_{\mathrm{Hm}+\mathrm{G} \mathrm{H}^{\prime}}$ the distributions of which were altered in the topsoil layer $(0.00-0.30 \mathrm{~m}$ layer) after 21 years under NT management, exhibited positive relationships with the estimated SSA and negative relationships with the TOC content (Table 3). In contrast, the $\mathrm{Fe}_{\mathrm{Fh}}$ content showed a negative relationship with SSA and a positive relationship with TOC (Table 3). The negative correlation between organic matter and the estimated SSA in the topsoil layer of the NT-managed soil is intriguing and should be investigated in future studies.

The processes associated with the rearrangement of pedogenic iron oxides in the total clay fraction after adopting NT soil management are similar to those described by Silva Neto et al. (2008) and Liptzin and Silver (2009) for aerobic pedoenvironments. The decreased content of the crystalline iron oxides (hematite, goethite, and maghemite) towards the uppermost no-tilled soil layers corroborates the hypothesis of reductive dissolution of these minerals and neoformation of metastable ferrihydrite, which should be assessed further in laboratory studies. The absence of soil disturbance and organic matter accumulation favors the presence of anaerobic micro sites, where $\mathrm{Fe}^{3+}$ can be reduced to $\mathrm{Fe}^{2+}$, as well as aerobic environments, where soluble $\mathrm{Fe}^{2+}$ reprecipitates

Table 3 - Correlation matrices between the assessed Fe content, the total organic $C$ content (TOC) in the ADFS fraction and in the total clay fraction (*) and estimates of the specific surface area (SSA) in the clay fraction of a Rhodic Paleudult under conventional tillage (CT) and no-tillage (NT) management.

\begin{tabular}{|c|c|c|c|}
\hline \multicolumn{4}{|c|}{$\mathrm{CT}$} \\
\hline & $\mathrm{SSA}-\mathrm{H}_{2} \mathrm{O}, \mathrm{m}^{2} \mathrm{~g}^{-1}$ & SSA-N ${ }_{2}, \mathrm{~m}^{2} \mathrm{~g}^{-1}$ & TOC, $\mathrm{g} \mathrm{kg}^{-1}$ \\
\hline $\mathrm{Fe}_{\mathrm{d}}, \mathrm{g} \mathrm{kg}^{-1}$ & ns & ns & ns \\
\hline $\mathrm{Fe}_{\mathrm{Fh}}, \mathrm{g} \mathrm{kg}^{-1}$ & ns & $\begin{array}{l}r=-0.626 \\
p=0.005\end{array}$ & ns \\
\hline $\mathrm{Fe}_{\mathrm{Mh}}, \mathrm{g} \mathrm{kg}^{-1}$ & ns & ns & ns \\
\hline $\mathrm{Fe}_{\mathrm{Hm}+\mathrm{Gt}}, \mathrm{g} \mathrm{kg}^{-1}$ & ns & ns & ns \\
\hline $\mathrm{SSA}-\mathrm{H}_{2} \mathrm{O}, \mathrm{m}^{2} \mathrm{~g}^{-1}$ & - & ns & $\mathrm{ns}^{*}$ \\
\hline SSA-N, $\mathrm{m}^{2} \mathrm{~g}^{-1}$ & - & - & $\mathrm{ns}^{*}$ \\
\hline \multicolumn{4}{|c|}{ NT } \\
\hline & $\mathrm{SSA}-\mathrm{H}_{2} \mathrm{O}, \mathrm{m}^{2} \mathrm{~g}^{-1}$ & SSA-N ${ }_{2}, \mathrm{~m}^{2} \mathrm{~g}^{-1}$ & TOC, $\mathrm{g} \mathrm{kg}^{-1}$ \\
\hline $\mathrm{Fe}_{\mathrm{d}}, \mathrm{g} \mathrm{kg}^{-1}$ & $\begin{array}{l}r=0.548 \\
p=0.019\end{array}$ & $\begin{array}{l}r=0.600 \\
p=0.009\end{array}$ & $\begin{array}{l}r=-0.475 \\
p=0.047\end{array}$ \\
\hline $\mathrm{Fe}_{\mathrm{Fh}}, \mathrm{g} \mathrm{kg}^{-1}$ & $\begin{array}{l}r=-0.602 \\
p=0.008\end{array}$ & $\begin{array}{l}r=-0.790 \\
p<0.001\end{array}$ & $\begin{array}{l}r=0.669 \\
p=0.002\end{array}$ \\
\hline $\mathrm{Fe}_{\mathrm{Mh}}, \mathrm{g} \mathrm{kg}^{-1}$ & $\begin{array}{l}r=0.696 \\
p=0.001\end{array}$ & $\begin{array}{l}r=0.875 \\
p<0.001\end{array}$ & $\begin{array}{l}r=-0.769 \\
p<0.001\end{array}$ \\
\hline $\mathrm{Fe}_{\mathrm{Hm}+\mathrm{Gt}}, \mathrm{g} \mathrm{kg}^{-1}$ & $\begin{array}{l}r=0.545 \\
p=0.019\end{array}$ & $\begin{array}{l}r=0.612 \\
p=0.007\end{array}$ & $\begin{array}{l}r=-0.477 \\
p=0.045\end{array}$ \\
\hline SSA- $\mathrm{H}_{2} \mathrm{O}, \mathrm{m}^{2} \mathrm{~g}^{-1}$ & - & $\begin{array}{l}r=0.869 \\
p<0.001\end{array}$ & $\begin{array}{c}r=-0.719^{*} \\
p<0.001\end{array}$ \\
\hline SSA-N, $m^{2} g^{-1}$ & - & - & $\begin{array}{c}r=-0.774^{*} \\
p<0.001\end{array}$ \\
\hline
\end{tabular}

in the form of metastable, poorly crystalline oxides (ferrihydrite). On the other hand, even a decreased content of the crystalline iron oxides crystais on surface soil layers was verified, the occurrence of differential illuviation of fine and coarse clay should not be disregarded mainly in no-tilled soil that show a continuous biological macro-pores matrix.

\section{Conclusions}

No-tillage increased the levels of organic C and low molecular weight organic compounds in the 0.00-0.05 and 0.00-0.15 m layers, respectively, compared to conventional tillage. In no-tilled soil, there is a decreased Fe content in to crystalline oxides (goethite, hematite, and maghemite) towards the uppermost soil layers, which is negatively correlated with the organic $\mathrm{C}$ content. In turn, the Fe levels associated with the poorly crystalline oxides (ferrihydrite), which are positively correlated with the organic $\mathrm{C}$ content, increased with the proximity to the soil surface.

The specific surface area, irrespective of the method used, was constant in the soil profile under conventional tillage management and decreased towards the uppermost soil layers in the NT-managed soil. This behavior of the surface area in NT-managed soil was negatively related to the levels of organic $\mathrm{C}$ and ferrihydrite, and positively related to the levels of maghemite and hematite + goethite. The organic $\mathrm{C}$ content appeared to have negative influence on the specific surface area of the total clay fraction, although the effects of the different iron oxide forms on this physical attribute merit further investigation.

\section{Acknowledgements}

To CNPq for providing fellowships to A.V. Inda and C. Bayer, and financial support under Universal Edital-2009 (process 470718/2009-9 and 478000/2009-0), and CAPES. This work was also partly co-funded by Spain's Ministry of Education and Science (Project CGL 2010-15067) and the European Regional Development Fund.

\section{References}

Bayer, C.; Martin-Neto, L.; Mielniczuk, J.; Pavinato, A.; Dieckow, J. 2006. Carbon sequestration in two Brazilian Cerrado soils under no-till. Soil Tillage Research 86: 237-245.

Bergamaschi, H.; Guadagnin, M.R.; Cardoso, L.S.; Silva, M.I.G. 2003. Climate of UFRGS Experimental Station and Covered Region. Editora da UFRGS, Porto Alegre, RS, Brazil (in Portuguese).

Bigham, J.M.; Fitzpatrick, R.W.; Schulze, D. 2002. Iron oxides. p. 323-366. In: Dixon, J.B.; Schulze, D.G., eds. Soil mineralogy with environmental applications. Soil Science Society of America Book Series, Madison, WI, USA.

Brown, G.; Brindley, G.W. 1980. X-ray diffraction procedures for clay mineral identification. p. 305-360. In: Brindley, G.W.; Brown, G., eds. Crystal structures of clays minerals and their X-ray identification. Mineralogical Society, London, UK. 
Bryant, R.B.; Macedo, J. 1990. Differential chemoreductive dissolution of iron oxides in a Brazilian Oxisol. Soil Science Society of America Journal 54: 819-821.

Colombo, C.; Barrón, V.; Torrent, J. 1994. Phosphate adsorption and desorption in relation to morphology and crystal properties of synthetic hematites. Geochimica et Cosmochimica Acta 58: $1261-1269$.

Cornell, R.M.; Schwertmann, U., eds. 2003. The Iron Oxides: Structure, Properties, Reactions, Occurrence and Uses. 2ed. VCH Publishers, Weinheim, Germany.

Dieckow, J.; Bayer, C.; Conceição, P.C.; Zanatta, J.A.; Martin-Neto, L.; Milori, D.B.M.; Salton, J.C.; Macedo, M.M.; Mielniczuk, J.; Hernani, L.C. 2009. Land use, tillage, texture and organic matter stock and composition in tropical and subtropical Brazilian soils. European Journal of Soil Science 60: 240-249.

Fitzpatrick, R.W.; Schwertmann, U. 1982. Al-substituted goethite: an indicator of pedogenic and other weathering environments in South Africa. Geoderma 27: 335-347.

Fontes, M.P.F.; Oliveira, T.S.; Costa, L.M.; Campos, A.A.G. 2000. Magnetic separation and evaluation of magnetization of Brazilian soils from different parent materials. Geoderma 96: 81-99.

Jeanroy, E.; Rajot, J.L.; Pillon, P.; Herbillon, A.J. 1991. Differential dissolution of hematite and goethite in dithionite and its implication on soil yellowing. Geoderma 50: 79-94.

Kämpf, N.; Schwertmann, U. 1982. The $5 \mathrm{M}-\mathrm{NaOH}$ concentration treatment for iron oxides in soil. Clays and Clay Minerals 30: 401-408.

Liptzin, D.; Silver, W.L. 2009. Effects of carbon additions on iron reduction and phosphorus availability in a humid tropical forest soil. Soil and Biochemistry 41: 1696-1702.

Mehra, O.P.; Jackson, M.L. 1960. Iron oxide removal from soils and clays by a dithionite-citrate system buffered with sodium bicarbonate. Clays and Clay Minerals 7: 317-327.

Muggler, C.C.; Van Loef, J.J.; Buurman, P.; Van Doesburg, J.D.J. 2001. Mineralogical and (sub)microscopic aspects of iron oxides in polygenetic Oxisols from Minas Gerais, Brazil. Geoderma 100: $147-171$.

North, P.F. 1976. Towards an absolute measurement of soil structural stability using ultrasound. European Journal of Soil Science 27: 451-459.

Quirk, J.P. 1955. Significance of surface areas calculated from water vapour sorption isotherms by use of the BET equation. Soil Science 80: 423-430.

Santos, N.Z.; Dieckow, J.; Bayer, C.; Molin, R.; Favaretto, N.; Pauletti, V.; Piva, J.T. 2011. Forages, cover crops and related shoot and root additions in no-till rotations to $\mathrm{C}$ sequestration in a subtropical Ferralsol. Soil Tillage Research 111: 208-218.
Schwertmann, U. 1964. Differentiation of soil iron oxides by extraction with ammonium oxalate-solution. Zeitschrift für Pflanzenernährung Düngung und Bodenkunde 105: 194-202 (in German).

Schwertmann, U. 1991. Solubility and dissolution of iron oxides. Plant and Soil 130: 1-25.

Schwertmann, U.; Fechter, H. 1984. The influence of aluminium on iron oxides. XI. Aluminium substituted maghemite in soils and its formation. Soil Science Society of America Journal 48: 1462-1463.

Schwertmann, U.; Taylor, R.M. 1989. Iron oxides. p. 379-438. In: Dixon, J.B.; Weed, S.B., eds. Minerals in soil environments. 2ed. Soil Science Society of America, Madison, WI, USA.

Silva Neto, L.F.; Inda, A.V.; Bayer, C.; Dick, D.P.; Tonin, A.T. 2008. Iron oxides in tropical and subtropical Brazilian Oxisols under long-term no-tillage. Revista Brasileira de Ciência do Solo 32: 1873-1881 (in Portuguese, with abstract in English).

Silva, A.R.; Souza Junior, I.G.; Costa, A.C.S. 2010. Magnetic susceptibility of B horizon of soils in the state of Paraná. Revista Brasileira de Ciência do Solo 34: 329-338 (in Portuguese, with abstract in English).

Souza Junior, I.G.; Costa, A.C.S.; Vilar, C.C.; Hoepers, A. 2010. Mineralogy and magnetic susceptibility of iron oxides of $\mathrm{B}$ horizon of Paraná state soils. Ciência Rural 40: 513-519 (in Portuguese, with abstract in English).

Torrent, J.; Barrón, V. 1993. Laboratory measurement of soil color: theory and practice. p. 21-33. In: Bigham, J.M.; Ciolkosz, E.J., eds. Soil color. Soil Science Society of America, Madison, WI, USA.

Torrent, J.; Barrón, V. 2008. Diffuse Reflectance Spectroscopy. p. 367-387. In: Ulery, A.L.; Drees, L.R., eds. Methods of soil analysis: mineralogical methods. Soil Science Society of America, Madison, WI, USA. (SSSA Book Series, 5).

Torrent, J.; Schwertmann, U.; Barrón, V. 1987. The reductive dissolution of synthetic goethite and hematite in dithionite. Clay Minerals 22: 329-337.

Zanelli, R.; Egli, M.; Mirabella, A.; Giaccai, D.; Abdelmoula, M. 2007. Vegetation effects on pedogenetic forms of $\mathrm{Fe}, \mathrm{Al}$ and $\mathrm{Si}$ and on clay minerals in soils in southern Switzerland and northern Italy. Geoderma 141: 119-129. 